\title{
OPEN Bio-process performance, evaluation of enzyme and non-enzyme mediated composting of vegetable market complex waste
}

\author{
V. Murugesan ${ }^{1} \&$ D. Joshua Amarnath ${ }^{2 \bowtie}$
}

Vegetable Market have become major sources of organic waste. Some of such waste when being diverted to landfills not only increase the landfill loading but also contribute to increase greenhouse gas emission. Of the many technologies available in handling such hugely generated waste, composting has proven very effective for decades. Enzyme and non-enzyme mediated aerobic composting of vegetable market complex waste (VMCW) have been investigated. Conventional composting technique though being capable of handling large quantum of waste are found to consume more time. Proven to be disadvantages factor. In the present investigation, the pre-cultured seed inoculums used for vegetable market complex waste, shortened the typical composting period from 45 to 9 days for the first time. Also, rapid size and volume reduction of VMCW was witnessed. The organic degradation of VMCW was observed as $42 \%(82 \pm 2.83 \%$ to $40.82 \pm 0.61 \%)$, with a volume reduction from $0.012 \mathrm{~m}^{3}$ to $0.003 \mathrm{~m}^{3}$ within 9 days. An enriched nutrients NPK level of compost biofertilizer was recorded as $0.91 \% \mathrm{w} / \mathrm{w}, 0.5 \% \mathrm{w} / \mathrm{w}$ and $1.029 \% \mathrm{w} / \mathrm{w}$ respectively. Compost maturity observed through the X-ray diffraction (XRD) analysis of the manure confirmed the conversion of the crystal structure of the compost particle to amorphous form and the mineralization of organic matter during the composting. Thus, the fermented pre-cultured seed inoculums favored an enhanced nutrients level with shortened composting time.

India generates about $1,57,478$ tons of municipal solid waste including vegetable market waste daily ${ }^{1}$. The capacity to treat the waste generated less than $20 \%$ and the remaining $80 \%$ waste is therefore dumped directly on to landfill without treatment. The municipal debris of Chennai corporation is dumped in Kodungaiyur (200 acres) and Perungudi (200 acres) dumpyard with the capacity of 2100- 2300 MT and 2200 to 2400 MT respectively. The unscientific dumping of waste in the landfills produced emissions of several greenhouse gases, majorly methane and carbon dioxide thereby contributing to global climate change ${ }^{2}$. To minimize the dumping of organic waste and thereby reducing greenhouse gas emission, several measures including composting are being experimented by investigated worldwide.

One of the main advantages of the biological aerobic composting method is that the organic waste compost conditions the soil and serves as fertilizers ${ }^{3-10}$. Researchers earlier observed that, as the VMCW gets degraded the size and volume reduce and the nutrients like nitrogen $(\mathrm{N})$, phosphorus $(\mathrm{P})$, potassium $(\mathrm{K})$ get released to enrich the soil. Finstein et al. ${ }^{11}$, Kayhanian et al. ${ }^{12}$, Elving et al. ${ }^{13}$. studied the composting of such waste in exclusively designed and fabricated reactor. The addition of microorganisms and invertebrates to enhance various biochemical reactions yielding mature compost were investigated. It was reported that such composting not only reduced the net greenhouse gas emissions but also enhanced the carbon nitrogen ratio and soil productivity. The compost thus obtained proved to increase agricultural productivity, soil biodiversity and reduce the ecological risks, creating a better living environment for the micro-flora, fauna and humankind. It was also observed that the unwanted pathogens were destroyed and the volume of waste reduced, favoring land filling process.

\footnotetext{
${ }^{1}$ Sathyabama Institute of Science and Technology, Chennai 600119, India. ${ }^{2}$ Department of Chemical Engineering, Sathyabama Institute of Science and Technology, Chennai 600119, India. ${ }^{\circledR}$ email: drjoshua.chem@ sathyabama.ac.in
} 
Moisture content, temperature, $\mathrm{C} / \mathrm{N}$ ratio, $\mathrm{pH}$ and coliform bacteria were chosen as parameters to control the quality, stability and efficiency of the composting process ${ }^{8,14-18}$. It has been reported that microbial decomposition of organic matter, occurs in the thin liquid (hygroscopic water) film around the surface of the particles enriched by water. During composting, the thin films of water surrounding individual particles are observed to dry off, making the microorganisms decomposing inorganic matter inactive. Thus, investigators concluded that the hygroscopic water around the waste particles to be a deciding factor in determining the efficiency of the composting process ${ }^{19}$. Temperature is reported to be a governing factor having an impact on the microbial activity during the composting process $s^{20,21}$. Temperatures below $20^{\circ} \mathrm{C}$ and above $60{ }^{\circ} \mathrm{C}$ contribute in slowing down the composting process. Having observed the influence of high temperature and reduced moisture content on the efficiency of the composting ${ }^{22,23}$ incorporated aeration not only to have an optimal control on temperature and moisture content but also maintain the oxygen level $\mathrm{l}^{20,21,24,25}$.

Traditional anaerobic and aerobic decomposition methods were reported to acieve mature compost in several months ${ }^{26-28}$. Recently developed techniques based on aerobic decomposition, reduced the composting period to about $4-5$ weeks ${ }^{29,30}$. Further, reducing the time was attempted by few other researchers and concluded that seed inoculums could increase the microbial population, and produce desired enzymes enhancing the conversion of organics and reducing the odorous gas emissions $\mathrm{s}^{31,32}$. However, less research on the enzyme activation and biokinetics modelling of aerobic composting are reported. Therefore, for the first time, an attempt has been made in formulating a precultured seed inoculum that can degrade VMCW by aerobic composting. To achieve size and volume reduction of VMCW by aerobic composting in a reduced time of seven days, a composter incorporated with shredding, aeration and mixing of VMCW has been designed, fabricated and used for the present study. This compact, easy to operate compacter for degradation of VMCW by aerobic composting is a novel attempt that not only reduces the size and volume of the waste but digest it in lesser time making the process viable. Further, the biokinetic modelling ${ }^{33}$ of the VMCW using the newly fabricated composter as also been investigated.

\section{Materials and methods}

Vegetable Market Complex Waste (VMCW). The vegetable market complex waste was collected from Tambaram Municipality (Latitude: $12.9229^{\circ} \mathrm{N}$, Longitude: $80.1275^{\circ} \mathrm{E}$ ) located in Chennai, Tamil Nadu, India. It is reported that the solid waste generated from Tambaram Municipality requires 19.27 acres of landfill.

Sample collection and shredding. Stratified random sampling technique was followed in order to eliminate the areas of non-uniform properties or concentrations which were identified and stratified. Thereafter, simple stratified random sampling technique was followed, so as to obtain a representative homogenous sample. The random sampling was done, where the vegetable market complex waste (VMCW) such as tomato, carrot, cabbage, radish, Ridge gourd, bottle gourd, brinjal, chayote, and beetroot were collected in mixed form and pooled further into a composite homogenized sample for the enhancement of composting processes.

Mechanical shredder for VMCW breakdown. The VMCW shredding process was carried out in two stages. Primarily, the collected VMCW sample was broken into manageable pieces approximately 1.5 to $2 \mathrm{cc}$, which was then fed into a secondary shredder for further size reduction approximately to $0.5-0.6 \mathrm{cc}$.

Aerobic Composting Reactor specifications. The composting reactor prototype as per design depicted in Fig. 1a is made up of SS316, with the sizing of $45 \times 30 \times 60$ in $\mathrm{cm}(\mathrm{L} \times \mathrm{B} \times \mathrm{H})$ and equipped with a manual stirring lever (Fig. 1b) with continuous aeration system through the air pump (capacity $230 \mathrm{~V}$ TID-75-P) (Fig. 1c) to maintain uniform homogenous mixing. The air enters the composting vessel (Fig. 1b) through the nozzle (Fig. 1c) and it was distributed through perforated holes in order to achieve uniform distribution of air throughout the vessel.

Preparation and feeding of an enzyme into the composting reactor. An attempt has been made to prepare an enzyme (pre-cultured seed inoculum) using Jaggery and curd. Gabhane et al. ${ }^{34}$ have investigated the compost using different additives/catalyst and concluded that high microbial enzymatic activity, organic matter degradation, bulk density, quality of finished compost including gradation, were observed in the Jaggery additives. In addition to this, Partanen et al. ${ }^{35}$, have reported that the acceleration and the mature end product of composting was achieved by the addition of curd. The investigation on composting of municipal solid waste with jaggery and curd as seed inoculum was prepared by mixing $200 \mathrm{~g}$ of Jaggery and $10 \mathrm{~g}$ of curd with $1 \mathrm{~L}$ of water and pre-cultured for 5 days at room temperature under static condition. Bulking agent (rice husk) was added for increasing the surface area of the substrate which could increase the microbial activity ${ }^{36}$. Eventually, the bulking agent was sieved out at the end of the composting process which can be used as seed compost since it has a greater number of bacteria attached.

Operation of aerobic bio composter. A sample of $12 \mathrm{~kg}$ (wet weight) Vegetable Market Complex Waste (VMCW) was taken and cut into small pieces of $0.5 \mathrm{~cm}$ in length using the mechanical shredder. The shredded vegetable market complex waste and seed inoculum with rice husk in the ratio of 16:1 was transferred into the composting reactor. The sample was collected on a daily basis at different depths before turning peddles and stored in a plastic container to monitor the composting process at room temperature. The parameters such as $\mathrm{pH}$, TS, VS, volume reduction and temperature (at different depths) of the VMCW were noted at every $24 \mathrm{~h}$. 


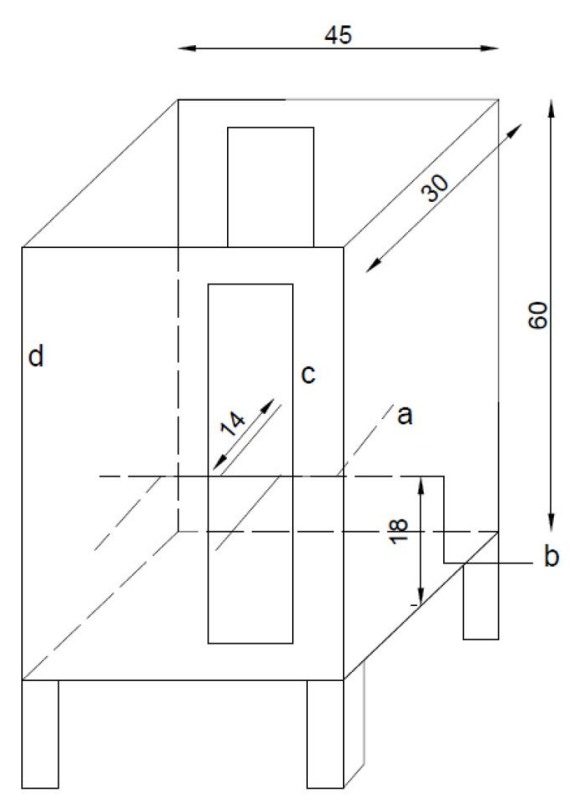

a)Aerobic Composter Design with Specifications

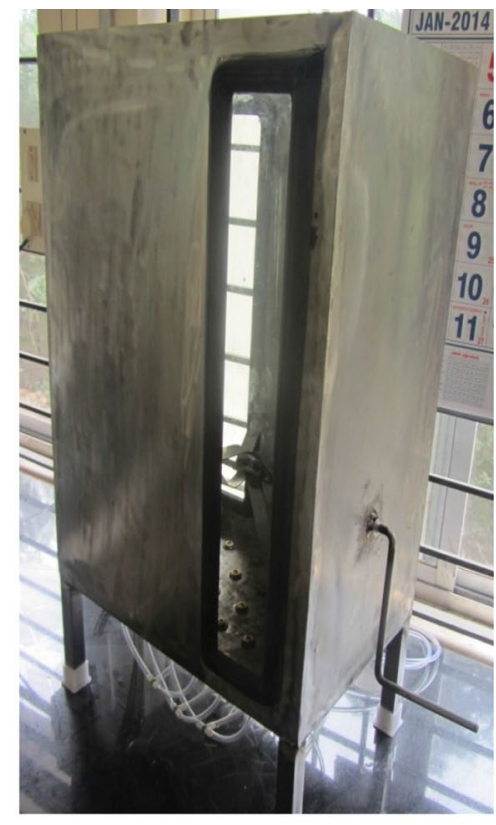

b)Aerobic Composter Prototype

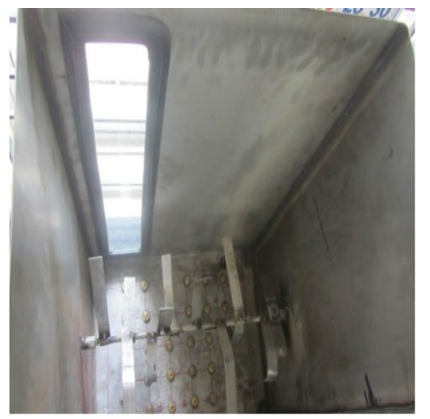

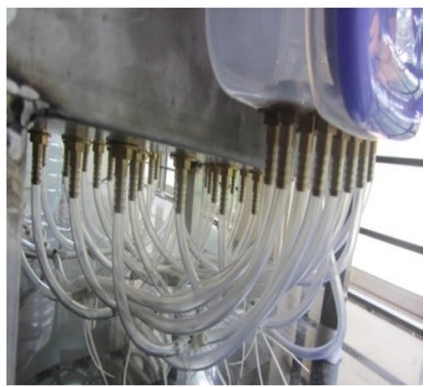

c)Aerobic Composter Prototype with blower and pedal view for aeration

Figure 1. Aerobic composting setup.

Characterization of Vegetable Market Complex waste (VMCW). The VMCW used as substrates were characterized with total solids (TS) (APHA, 2540B), volatile solids (VS) (APHA, 2540G) and fixed solids (FS) (APHA, 2540E) using standard methods for the examination of water and wastewater ${ }^{37}$. The moisture content of the sample was measured after oven-dried at $105{ }^{\circ} \mathrm{C}$ for overnight ${ }^{37}$. The oven-dried sample was ground using pestle and mortar and then used for further analysis. The organic matter was calculated from the ash after igniting the sample (dry weight) in a muffle furnace at $550{ }^{\circ} \mathrm{C}$ for $2 \mathrm{~h}^{37}$. The $\mathrm{pH}$ of the compost was determined immediately upon collection of samples from the reactor by adding distilled water under the condition of solid to water ratio $(1: 10 \mathrm{w} / \mathrm{v})^{9}$. The temperature in the bioreactor was measured manually during sample collection using a glass thermometer.

CHNS analysis. The elemental compositions such as carbon $(\mathrm{C})$, hydrogen $(\mathrm{H})$, nitrogen $(\mathrm{N})$ and sulphur (S) of each organic waste were determined using CHNS analyzer (Model Euro vector 3000 series, Italy) (ASTM D-5291) available in CATERS CSIR-CLRI, Chennai, India and quantified based on the dry weight. The total and volatile solids were estimated using standard methods for the examination of water and wastewater ${ }^{37}$. An aliquot of the sample was oven-dried at $105^{\circ} \mathrm{C}$ and kept in a desiccator prior to analysis then known weight of the dried VMCW was taken into an aluminium boat and the sample initial weights were noted. Thereafter, the boats were loaded in the CHNS analyzer and increased peak, the calibration graph was used to quantify the CHNS ${ }^{38}$. The oxygen content was calculated by the difference between VS and the total sum of C, N, H, S ${ }^{39}$. The calorific energy value (CEV) was estimated using Eq. (1) proposed by Channiwala et al. ${ }^{40}$.

$$
\mathrm{CEV}(\mathrm{MJ} / \mathrm{kg})=0.3491 \mathrm{C}+1.1783 \mathrm{H}-0.10340-0.0151 \mathrm{~N}-0.0211 \mathrm{~A}
$$

where, $\mathrm{CHNO}$ and A represents a percentage of carbon, hydrogen, nitrogen, oxygen and ash on dry weight basis.

$X R D$ analysis. The overall structural changes during the decomposition of wastes were studied using X-Ray diffraction method. Prior to analysis, the sample was dried at $50{ }^{\circ} \mathrm{C}$ for $24 \mathrm{~h}$ and was ground to fine powder. The spectra were recorded on Bruker D8 Powder XRD instrument using the source Copper K alpha (CSIR-CLRI, Chennai).

Microbial growth rate in the composter. $1 \mathrm{~g}$ (wet weight) of composting sample was taken from the composting reactor at $24 \mathrm{~h}$ interval and serially diluted with $9 \mathrm{~mL}$ of sterile distilled water up to $10^{-9}$ dilution. Then $1 \mathrm{~mL}$ of the $10^{-2}$ to $10^{-8}$ the diluted sample was dispensed into a sterile petri dish with a molten Nutrient agar and gently swirls to solidify. The solidified plates were stored for $24-48 \mathrm{~h}$. The microbial growth was expressed in CFU/g dry weight of total solids.

Kinetics. Substrate concentration (S), and the consumption rate of the substrate (r) were observed during the composting period. The reciprocals of reaction rate $(1 / \mathrm{r})$ and Substrate concentration $(1 / \mathrm{S})$ were computed using 


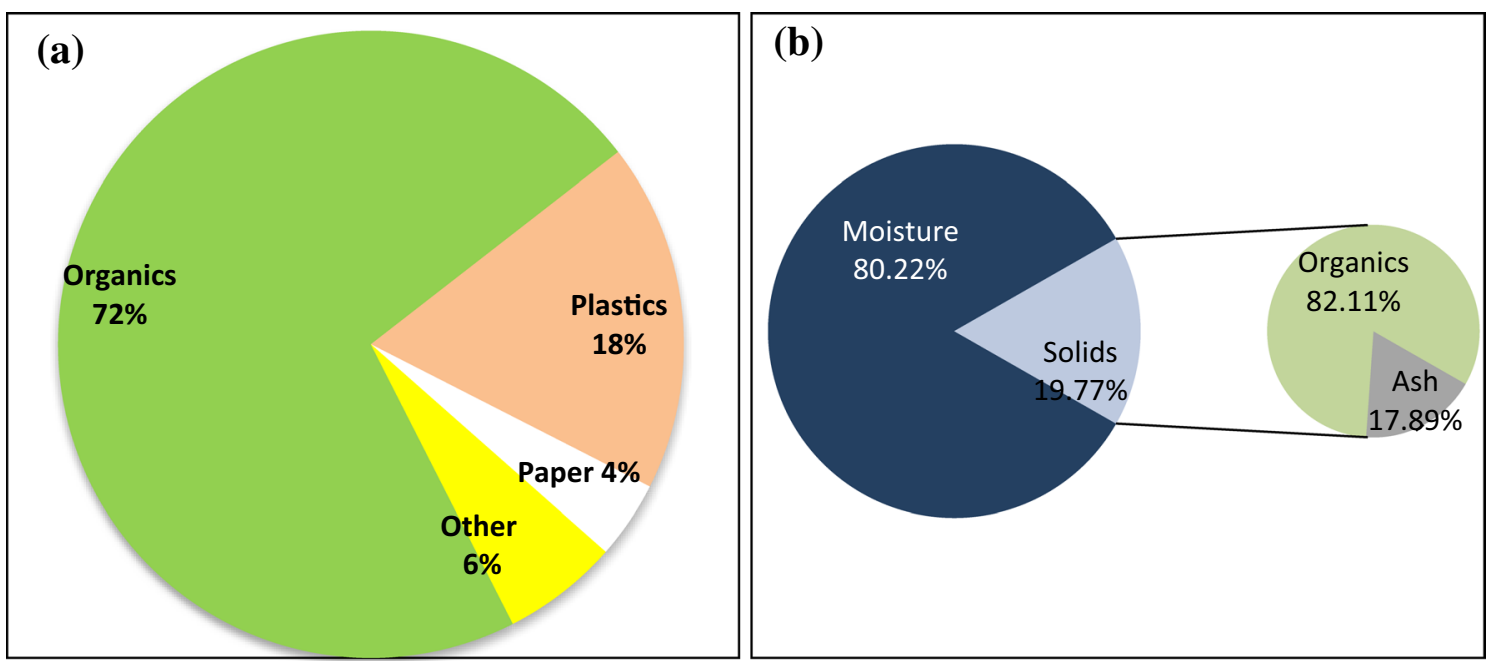

Figure 2. (a) Composition of VMCW at source. (b) Composition after sample collection.

\begin{tabular}{|l|l|c|}
\hline Parameter & Initial & \multicolumn{1}{|l|}{ Final } \\
\hline $\mathrm{C} / \mathrm{N}$ & 13.84 & 2.35 \\
\hline Empirical formula & $\mathrm{C}_{16} \mathrm{H}_{25} \mathrm{NO}_{4}$ & $\mathrm{C}_{10} \mathrm{H}_{17.9} \mathrm{~N}$ \\
\hline $\mathrm{CEV}(\mathrm{kJ} / \mathrm{kg}$ of $\mathrm{TS})$ & 25.05 & 19.45 \\
\hline
\end{tabular}

Table 1. Characterization of VMCW.

a Lineweaver-Burk plot. In the Lineweaver-Burke plot, the intercept on the $\mathrm{y}$-axis gives the value of $\mathrm{K}_{3}$, whereas the value of $\mathrm{K}_{\mathrm{m}}$ is obtained from the slope of the line and the linear regression was obtained between $1 / \mathrm{r}$ and $1 / \mathrm{S}$.

\section{Results and discussion}

The aerobic composting was performed using novel pre-cultured seed inoculums in addition to the aeration and peddling system. The evaluation of the size and volume reduction with composting period revealed the effect of Jaggery and curd based pre-cultured inoculums which are detailed in the following sections.

Characteristics of the VMCW. The composition of VMCW collected from the Tambaram Municipality was quantified as $72 \%$ of organics, $18 \%$ of plastics, $4 \%$ of paper and $6 \%$ of miscellaneous from the complete source segregated, collected, weighed samples (Fig. 2a). Since it was separated at source, VMCW was taken for the aerobic composting operation which contains more than $80 \%$ organic waste (Fig. $2 \mathrm{~b}$ ) and the neutral $\mathrm{pH}$ of 6.8 was observed which favors microbial activity.

The initial total solids content was observed in the range of $19-22 \%$ (Fig. 2b). The initial volatile solid content observed was $82.11 \pm 2.83 \%$ (Fig. 2b) illustrated a high fraction of organics in Vegetable Market Complex Waste consistent with results reported by Pellera et al. ${ }^{41}$. The empirical formula was calculated as reported as $\mathrm{C}_{16} \mathrm{H}_{25} \mathrm{NO}_{4}$ for the primary sedimentation tank sludge which indicates that the waste contains a lower value of degradable/ non-degradable nitrogen content depicted higher $\mathrm{C} / \mathrm{N}$ ratio at the end of the experiment (Table 1$)^{42}$.

Effects of moisture and temperature. Initial decomposition was carried out by mesophilic microorganisms thrived at 29.7 to $36{ }^{\circ} \mathrm{C}$ temperatures. Due to fine grinding of the VMCW, high moisture content $(80.22 \pm 0.34 \%)$ was observed initially, that has reduced the $\mathrm{O}_{2}$ uptake level and lowers the biodegradability potential of VMCW which was consistent with results reported by Kalamdhad et al. ${ }^{43}$. In order to reduce the impact of moisture content, the bulking agent rice husk was mixed with VMCW, which further improved the surface area and dryness for microbial growth inside the reactor. Eventually, the matured compost with a reduced moisture content of $18.37 \pm 0.29 \%$ (9th day) was observed at the end of the composting process (Fig. 3a) ${ }^{44}$.

The decreasing trend in moisture content observed was attributed to temperature and metabolic activity of VMCW, whereas the sample had high moisture content at the initial phase of composting reducing the oxygen supply. However, the reactor itself recovered from this drop of oxygen supply. The temperature was estimated at various depths (Fig. 4a) and every acuity achieved the estimation of $54 \pm 9.27$ on the third day, demonstrating that the heap had reached the thermophilic stage. The observed rapid reduction of moisture content (64\%) on the 3 rd day was attributed to the system acquired temperature by the metabolic enzymatic activity of microorganism for the protein degradation (Fig. 4a). This was confirmed with a decreased level of $\mathrm{C} / \mathrm{N}$ ratio, degradation rate (VS 6.6\%/ day) and reduction rate (volume reduction $3.2 \mathrm{~L} /$ day) $)^{45-48}$. Eventually, the temperature drop was observed at the final stage and, thereafter no reduction in temperature was observed attributed to insufficient 


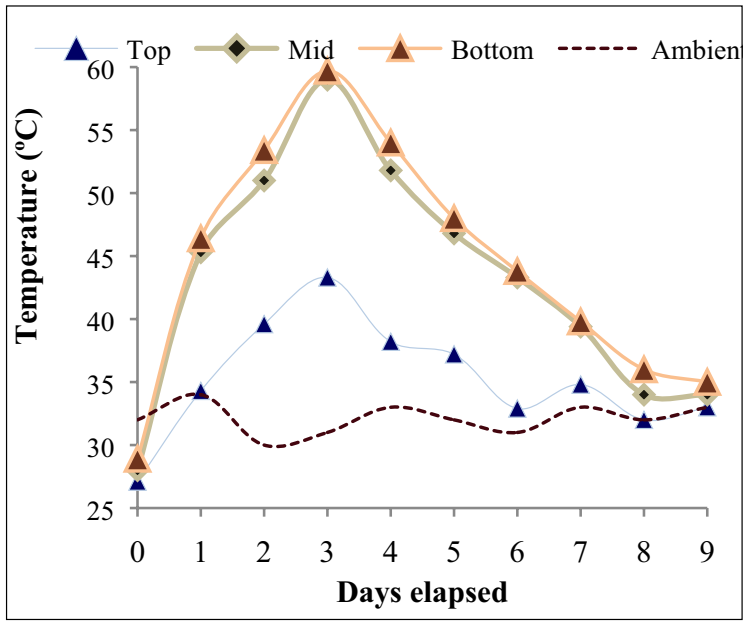

(a)

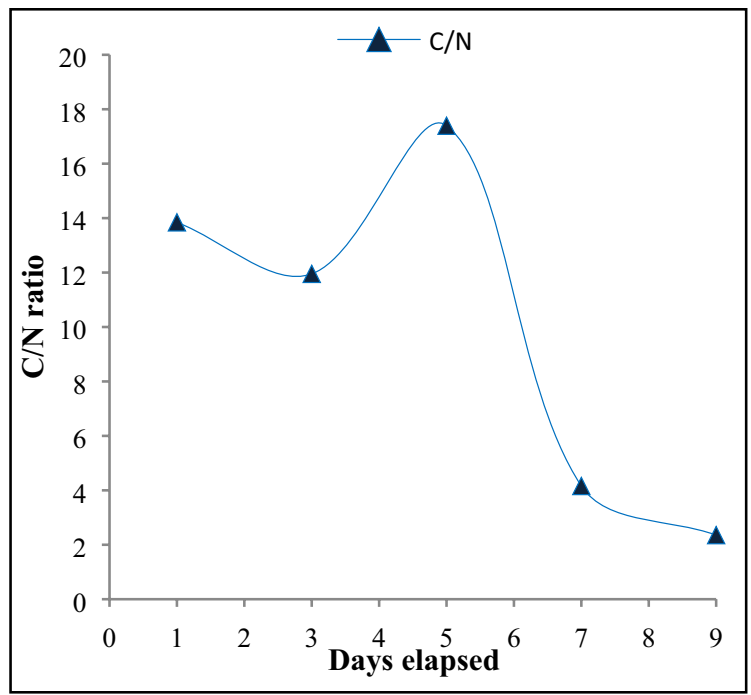

(c)

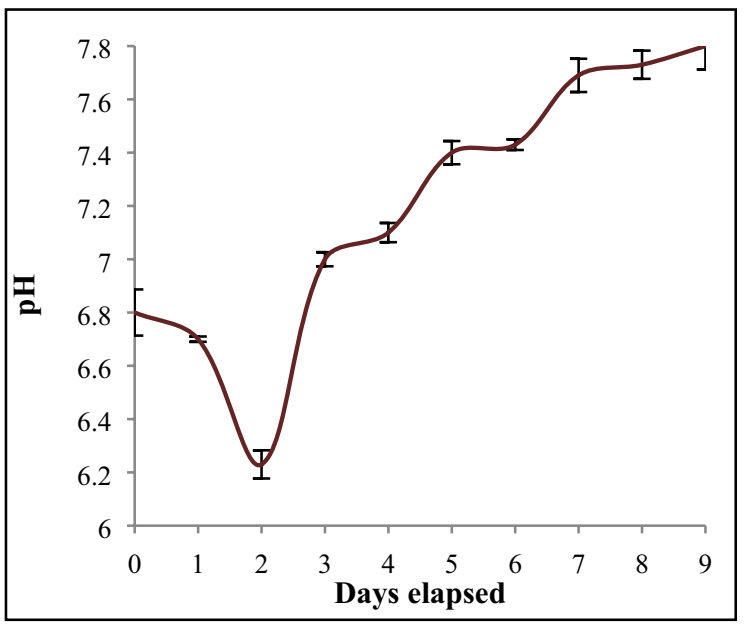

(b)

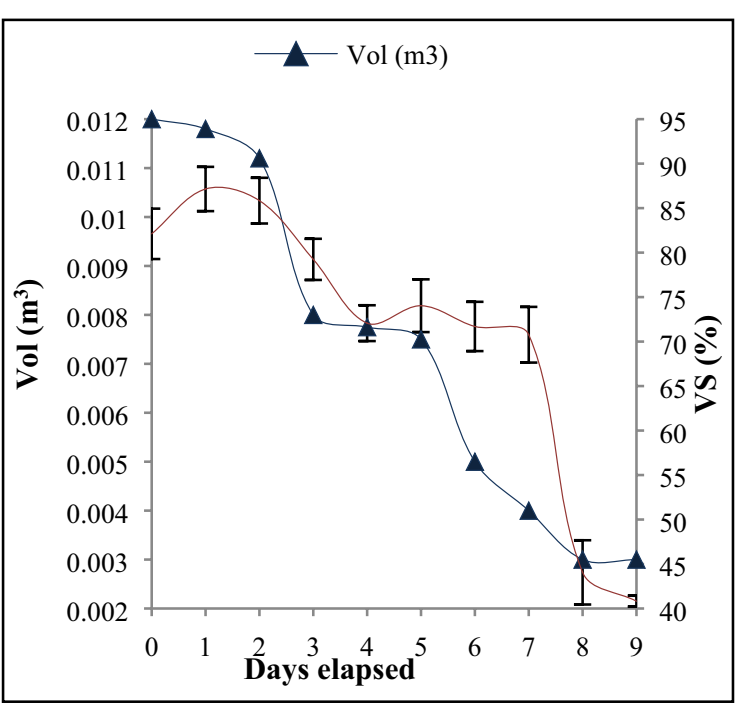

(d)

Figure 3. (a) Effect of temperature on composting, (b) effect of $\mathrm{pH}$ on composting, (c) effect of $\mathrm{C} / \mathrm{N}$ ratio during the composting process, (d) evolution of volume reduction organic strength reduction and mineralisation.
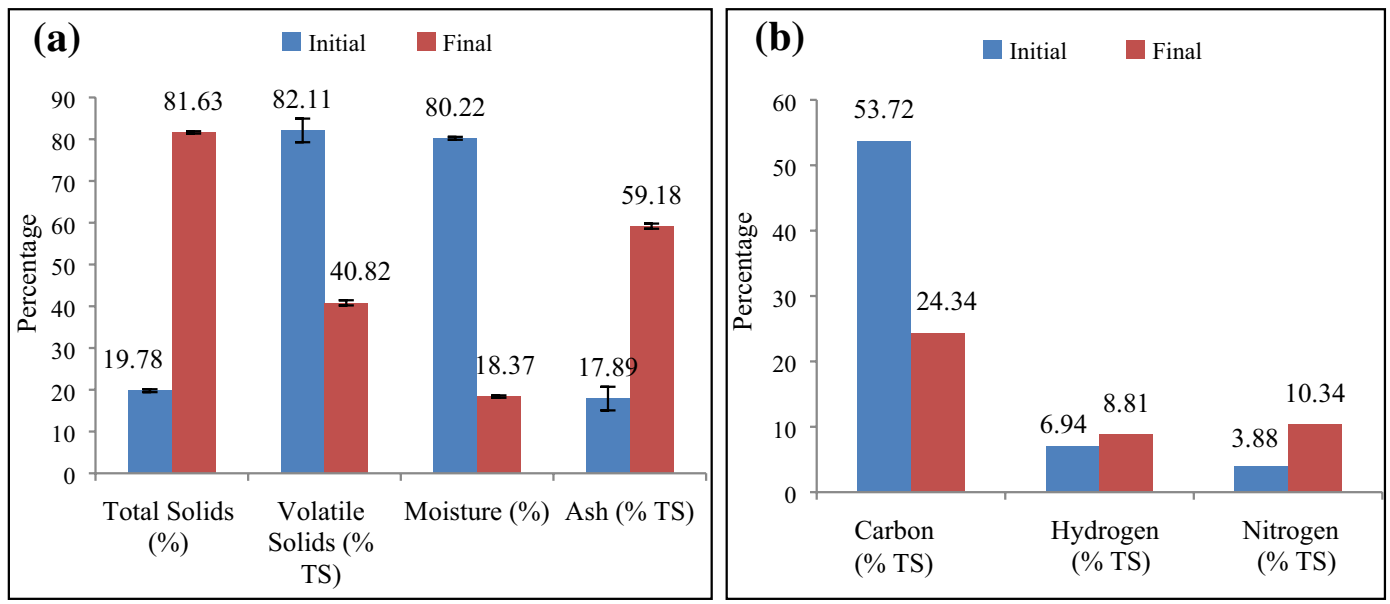

Figure 4. (a) VMCW at Initial and Final stage of composting, (b) CHN concentration at Initial and Final stage of composting. 
bulk volume $(3 \mathrm{~L})$ and the liberation of excessive heat which indicates the completion of the aerobic composting process and production of matured manure.

Effects of $\mathrm{pH}$ on composting. $\mathrm{pH}$ is the most influenced parameter in the solid waste biochemical metabolic reactions, which allows microorganisms to degrade the complex substances and increases the solubility of mineral elements during composting. The initial $\mathrm{pH}$ of $6.8 \pm 0.08$ (Fig. 3b) was observed for VMCW, enhance the growth of micro-organism could lead to high volume reduction, was supported by Khan et al. ${ }^{49}$, Zorpas et al. ${ }^{50}$. Further, the $\mathrm{pH}$ of the reactor was decreased to 6.23 on the $2 \mathrm{nd}$ day was attributed to the rapid particulate hydrolysation by high microbial of $2.9 \times 10^{-6} \mathrm{CFU} / \mathrm{g}$ (Fig. 8) and enzymatic activity during the aerobic microbial metabolism in addition to the high temperature of $53{ }^{\circ} \mathrm{C}$ on 2 nd day which increases the hydrogen ion concentration. Similarly, reports have been revealed that the disintegration of bigger sized substrate inhibits the oxygen supply, which could lead to anaerobic condition causes acid accumulation in the substrate that has reduced the $\mathrm{pH}$. Subsequently, a gradual increase in $\mathrm{pH}$ to 7.8 was observed with days elapsed (3rd to 9th day) (Fig. 3b) which was attributed to proteinaceous degradation and formation of ammonia bicarbonate contributed to alkalinity which was prolonged up to the end of the experiment. This has favored adequate growth of microorganism in moderately alkaline condition. Supporting to this, decreased $\mathrm{pH}$ up to $5.5 \mathrm{on}$ 3rd day and thereafter increased $\mathrm{pH}$ of 8.5 up to end of the matured manure production period was observed by Gabhane et al. ${ }^{34}$.

Effects of carbon-nitrogen ratio on composting. The maxima and minima $\mathrm{C} / \mathrm{N}$ ratio were observed as 17.39 and 2.35 on 5th day and 9th day respectively (Fig. 3c) was attributed to the low and high complexity of carbohydrate and protein compound degradation. The study focused on the effect of pre-cultured seed inoculums on compost and its maturity ( $\mathrm{C} / \mathrm{N}$ ratio) (Fig. 3c). The $\mathrm{C} / \mathrm{N}$ ratio was slightly reduced (11.95) during the thermophilic phase (3rd day) attributed to a high rate of degradation of carbohydrates where the aeration got disturbed due to the hydrolysation. This was in line with the study reported by Chai et al. ${ }^{51}$.

Consequently, slow degradation of protein compounds into ammonia reduces the nitrogen compound, thereby increasing trend of $\mathrm{C} / \mathrm{N}$ ratio of 17.39 was observed up to 5 th day which was corroborated well with high volume reduction (56\%) (Fig. 3d) on the 5th day. This was consistent with results reported by Awasthi et al. ${ }^{52}$. Subsequently, the fall in the $\mathrm{C} / \mathrm{N}$ ratio was observed could be regarded as being caused by microbial respiration due to the rapid uptake of available organic carbon by microorganisms. Thus, large amounts of $\mathrm{CO}_{2}$ were liberated leading concomitantly to an increased proportion of total nitrogen of the medium from $3.88 \%$ to $10.39 \%$ (Fig. 4b) which was consistent with the results of Karak et al. ${ }^{53}$, Awasthi et al. ${ }^{52}$. Eventually, the minimum carbon $(24.35 \%)$ and maximum nitrogen $(10.33 \%)$ on 9 th day (Fig. $4 \mathrm{~b}$ ) was lower than the initial $\mathrm{C} / \mathrm{N}$ ratio evidenced the perfect aerobic degradation and maturity of manure which was consistent with the maximum volume reduction of $77 \%$ (Fig. $3 \mathrm{~d})^{54}$.

Volume and organic strength reduction in compost. The volumetric reduction of VMCW depends on the microbial degradation of the organic content available for composting reaction and moisture level inside the composter. In enzymatic pre-cultured seed inoculum-based composting, reduction in size of the material depends on the degree of hydrolysis of substrate by the bacteria replenishing enzymes which breakdown the complex polymeric organic materials into simpler ones. The volume of the compost material was decreased day by day with increased composting time (Fig. 3d), from $0.012 \mathrm{~m}^{3}$ on 0 th day to $0.003 \mathrm{~m}^{3}$ on 9 th day. The low initial rate of reduction in volume $\left(0.0002 \mathrm{~m}^{3} /\right.$ day on $1^{\text {st }}$ day and $0.0006 \mathrm{~m}^{3} /$ day on 2 nd day) observed was attributed to the insufficient oxygen supply for aerobic microbes resulting from the high initial moisture in the substrate which reduces the air supply on the top and the middle surface of the composter. This was consistent with the results reported by Makan et al..$^{55}$.

High volume reduction was recorded on $3 \mathrm{rd}$ day $\left(0.0032 \mathrm{~m}^{3} /\right.$ day $)$ which was attributed to the initial settlement of VMCW on the reactor due to reduced moisture content and further confirmed by the high microbial activity on 3rd day $\left(3.6 \times 10^{-6} \mathrm{CFU} / \mathrm{g}\right)$ (Fig. 8 ) which was consistent with volatile solids reduction beyond 3rd day. Thereafter, gradual volume reduction was observed with elapsed time. Eventually, no volume reduction was observed on 8th and 9th day of the composting period, as the composting is completely depending on the volume of voids in the waste and further, attainment of shrinkage limit of waste due to reduced moisture content along with converted matured manure didn't have any effect on volume reduction. The decreased trend in VS was noticed from 2 nd to 8 th day (Fig. 3d) during the mesophilic and thermophilic phases of the composting and this change of the volatile solid content during composting was used to assess mineralization and decomposition of organic matter ${ }^{56}$. Eventually, the VS content reached relatively the stable form on 9th day which reveals that the substrate conversion had reached a stable phase and was matured. It was observed that, $82 \pm 2.83 \%$ of TS was volatilised during the composting process and this loss contributed to the degradation of organic compounds (Table 2$)^{57}$.

High correlation $\left(\mathrm{R}^{2}=0.862\right)$ (Fig. $5 \mathrm{a}$ ) between the percentage of volatile solids and percentage of volume reduction was observed for VMCW indicated that stabilization of organic content into manure which normally mineralized to nitrogen $(\mathrm{N})$, phosphorus $(\mathrm{P})$ and potassium $(\mathrm{K})$ in addition to the other components with an organic mass in the volume of the composting reactor. The energy loss during the conversion of waste into manure was observed as $5600 \mathrm{~kJ} / \mathrm{kg}$ of TS attributed to the decomposition of carbohydrates and protein compounds. Supporting to this the organic carbon decreased by $29.375 \%$ which was consistent with observed the volatile solids reduction of $40.6 \pm 0.61 \%$. This conforms the utilization of carbon for aerobic degradation and mineralization to mature compost was further confirmed with high correlation $\left(R^{2}=0.913\right)$ between volatile solids and CEV (Fig. 5b).

Moreover, the calorific energy value (CEV) of the manure was observed to be as $19,450 \mathrm{~kJ} / \mathrm{kg}$ of DM evidenced the maturity and further confirmed by the reduction of moisture to less than $15 \%$ on 9 th day. This was 


\begin{tabular}{|l|l|l|l|l|l|l|l|l|}
\hline Days elapsed & TS (\% of waste) & VS (\% of TS) & Ash (\% of TS) & $\begin{array}{l}\text { Moisture (\% of } \\
\text { waste) }\end{array}$ & C (\% TS) & H (\% TS) & N (\% TS) & C/N ratio \\
\hline 0 & $19.78 \pm 0.35$ & $82.11 \pm 2.83$ & $17.89 \pm 2.83$ & $80.22 \pm 0.35$ & 53.72 & 6.94 & 3.88 & 13.84 \\
\hline 3 & $35.89 \pm 3.09$ & $79.24 \pm 2.31$ & $20.76 \pm 2.31$ & $64.11 \pm 3.09$ & 73.00 & 5.44 & 6.10 & 11.95 \\
\hline 5 & $45.71 \pm 7.17$ & $74.03 \pm 2.96$ & $25.97 \pm 2.96$ & $54.29 \pm 7.17$ & 74.62 & 12.01 & 4.29 & 17.39 \\
\hline 7 & $55.89 \pm 2.81$ & $70.77 \pm 3.13$ & $29.23 \pm 3.13$ & $44.11 \pm 3.13$ & 37.18 & 5.50 & 4.34 & 4.16 \\
\hline 9 & $81.63 \pm 0.29$ & $40.82 \pm 0.62$ & $59.18 \pm 0.62$ & $18.37 \pm 0.29$ & 24.35 & 8.81 & 10.94 & 2.35 \\
\hline
\end{tabular}

Table 2. Vegetable Market Complex Waste (VMCW) Composition.

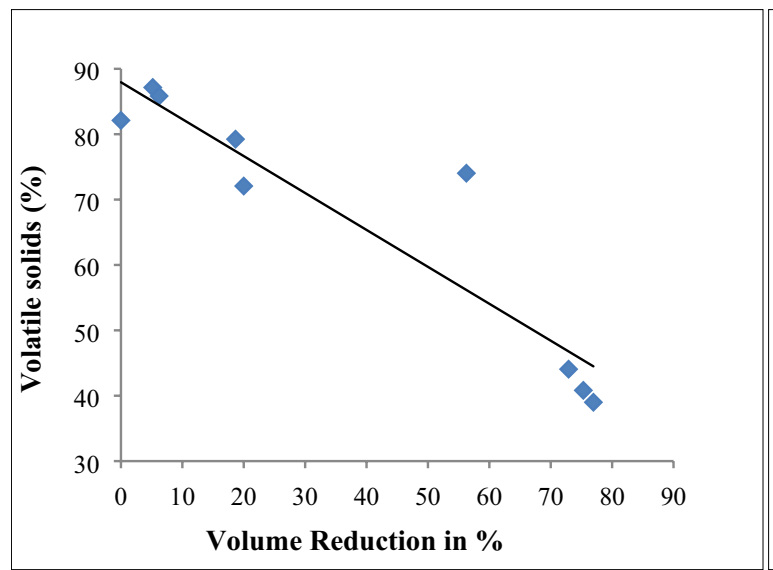

(a)

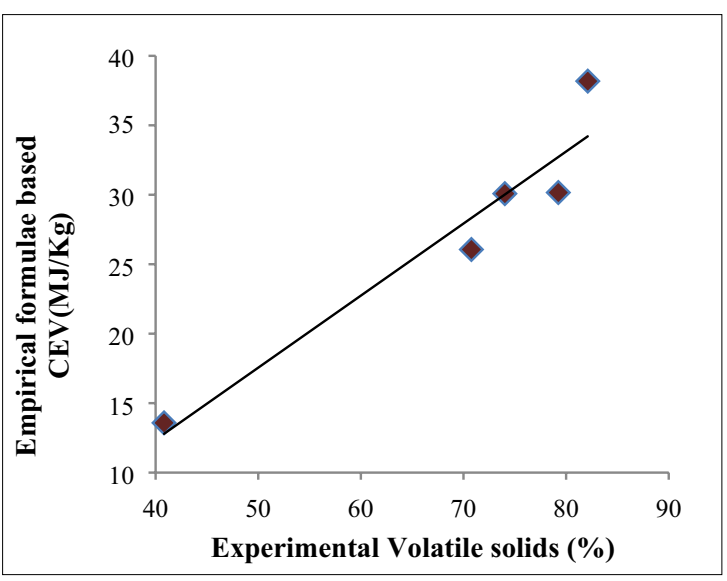

(b)

Figure 5. Linear relation between (a) VS and Volume reduction, (b) VS and CEV.

consistent with results reported by Stainforth et al. ${ }^{58}$ for wheat straw $17,600 \mathrm{~kJ} / \mathrm{kg}$. On the contrary, the maturation and stabilization pressure for the change of ammoniacal nitrogen to nitrate nitrogen and further conversion took 14 weeks, where the calorific energy value of the manure observed to be $10,000 \mathrm{~kJ} / \mathrm{kg}$ DM with a moisture content of $12 \%$ are reported by Raclavska et al..$^{59}$. This was in line with the results reported by many researchers and evaluated the CEV ranged from 7000 to $20,000 \mathrm{~kJ} / \mathrm{kg}$. For instance, the CEV of $8092 \mathrm{~kJ} / \mathrm{kg}$ for bio-solids and wood chips was observed by Ekinci et al. ${ }^{60}$. Similarly, Steppa et al.$^{61}$ reported for organic waste as $9000-11,000 \mathrm{~kJ} /$ $\mathrm{kg}$, which was lower than that reported by Sobel and Muck ${ }^{62}$ for poultry droppings $(12,800 \mathrm{~kJ} / \mathrm{kg})$, whereas the paper mill sludge and poultry manure compost reported CEV of $3649 \mathrm{~kJ} / \mathrm{kg}$, and for $5111 \mathrm{~kJ} / \mathrm{kg}$ for straw and poultry manure compost ${ }^{63}$.

XRD spectra of crystallised mature manure. Diffraction designs were contracted utilizing a goniometer. X-beam diffraction spectra of VMCW at various development stages (0th and 9th) as appeared in Fig. 6. It was seen that the quantity of exceptional peaks presents in spectra on 0th day test has diminished towards the 9th day of the treating the soil cycle, while less serious pinnacles expanded towards later phases of the treating the soil cycle.

This demonstrates the transformation of strong squanders from translucent to vague during the degradation cycle, showing that the cellulose and different polysaccharides mixes were corrupted. This was reliable with results for the humidification and developing cycle of the excrement straw detailed by $\mathrm{Hu}$ et al. ${ }^{64}$.

Effects of the enzyme on the mineral nutrient of matured compost. The concentration of mineral nutrients such as Nitrogen $(\mathrm{N})$, Phosphorous $(\mathrm{P})$ and Potassium $(\mathrm{K})$ was observed as $0.918 \%, 0.5 \%$ and $1.029 \%$ respectively for the matured manure produced at reduced composting time of 9 days. It was observed that the NPK concentration in the obtained compost manure on 9th day was comparable with other literature (Fig. 7) reported the composting manure nutrients produced at 45-75 days. This reveals that the high activity of Jaggery based seed inoculums converts the high solid waste molecules into nutrients in the short time period of 9 days.

Supporting this, the N, P and K value was $0.9 \%, 0.28 \%$ and $0.0487 \%$ respectively and reported that the availability of these nutrients was high in Jaggery based enzyme when compared with other enzymes, which are based on fly ash, phosphor gypsum, lime, and polyethene glycol revealed by Gabhane et al. ${ }^{34}$. Similarly, value of $\mathrm{N}, \mathrm{P}$ and $\mathrm{K}$ in the MSW compost varied from $0.9 \%, 0.27 \%$ and $0.55 \%$ respectively was addressed by Saha et al. ${ }^{65}$.

Kinetic modelling of enriched microbial composting. To analyze the effect of pre-cultured seed inoculums on VMCW composting process, the total microbial growth counts of the composting system were examined. The maximum microbial growth rate of $3.47 \times 10^{-6} \mathrm{CFU} / \mathrm{g}$ was observed on 4 th day (Fig. 8) whereas, in the normal composting process, the microbial consortia activity was delayed due to the acclimatization of the 


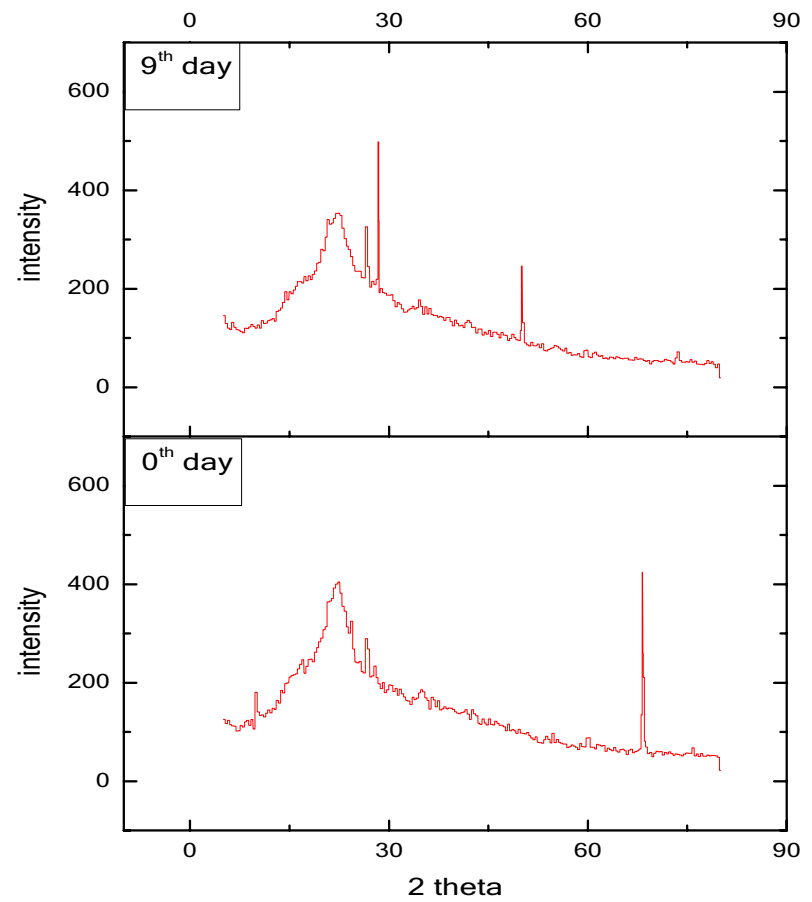

Figure 6. XRD spectra of VMCW compost.

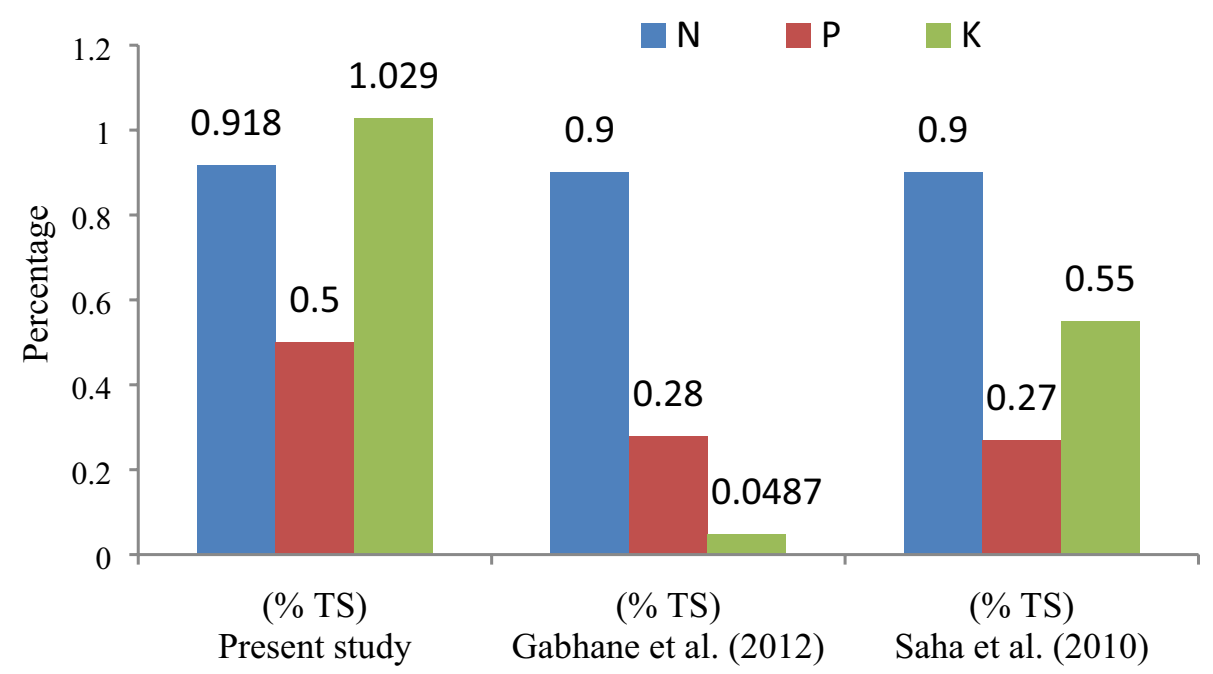

Figure 7. Comparison of NPK of present study with published results.

same to the vegetable waste which has increased the composting time. This could lead to odour production and maggot formation. The sharp lag phase observed on 2nd day was attributed to the high adaptability of microbes and the decomposition of the substrate which was confirmed by the acidic the $\mathrm{pH}$ of 6.2 . Further, the exponential and declining microbial growth phases observed was evidenced in the short period of acclimatization and maturity (Fig. 8). In addition, the exponential growth phase was prominent on 3rd day and stationary phase was observed until the 5 th day which reveals that the shortened stationary phase was attributed to efficient utilization of enzymes. Moreover, the microbial growth has coincided well with high VS, volume reduction and optimum temperature (Fig. 3a), pH (Fig. 3b) and $\mathrm{C} / \mathrm{N}$ ratio (Fig. 3c). Declining phase depicted afterwards, where the microbial activity occurs on the thin films of water surrounded on the substrate. Thereafter, this hygroscopic water was dried so that the microbial activity was arrested at the end of the experiment, which was consistent with temperature (Fig. 3a), pH (Fig. 3b), C/N (Fig. 3c), Volume reduction (Fig. 3d).

The two stages of pre-cultured seed inoculum the composting process were based on microbial population for the former stage and substrate concentration for the later stage as a limiting factor. Initially, organic matter was sufficient to be decomposed where the microbial population was insufficient which limits the composting 


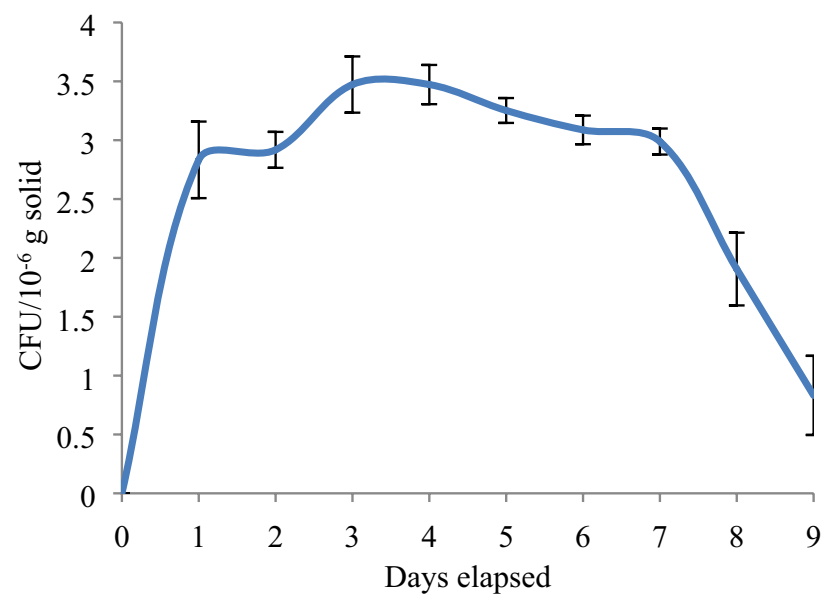

Figure 8. Microbial growth rate of composting process.

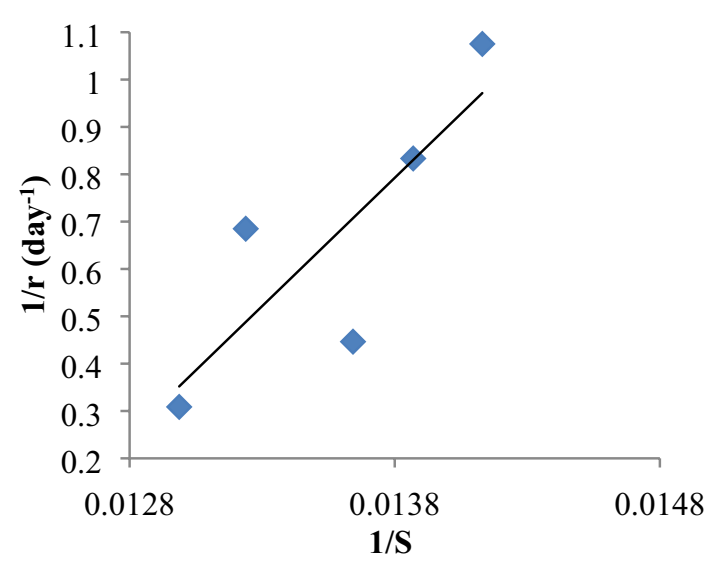

Figure 9. Determination of bio-kinetic constants.

process. Thereafter, the microbial concentration was increased with decreased organic matter concentration which could lead to reduced heat due to low metabolic activity which was insufficient to maintain the composting temperature so that the substrate became the limiting factor for the composting process. The fundamental microbial kinetics were plotted and analysed was used to examine the efficiency of inoculation during the aerobic composting processes with reference to the Xi et al. ${ }^{66}$.

The organic matter was plotted against composting time and the reaction rate $(r)$ was determined by drawing the tangential resultant curve. The reciprocals of reaction rate $(1 / \mathrm{r})$ and Organic matter $(1 / \mathrm{S})$ were computed (Fig. 9). The Michaelis-Menten constant $\left(\mathrm{K}_{\mathrm{m}}\right)$ and limiting velocity reaction rate constant $\left(\mathrm{K}_{3}\right)$ for the composting reactor was 81.06 and 0.15 respectively. The reaction rate $(\mathrm{r})$ of the aerobic composting was very high especially on 8 th day which was observed as $26.71 \% /$ day. This has depicted a high degradation potential of VMCW. Hence, the addition of enzymes proved to be attained rapid degradation of organic waste during composting under aerobic condition.

The Michaelis-Menten constant $\left(\mathrm{K}_{\mathrm{m}}\right)$ and limiting velocity reaction rate constant $\left(\mathrm{K}_{3}\right)$ for the composting reactor was 81.06 and 0.15 respectively. The reaction rate $(\mathrm{r})$ of the aerobic composting was very high especially on 8 th day $(26.71 \% /$ day), depicted a high degradation potential of VMCW. Hence, the addition of enzymes proved to be a rapid degradation of organic waste during composting under aerobic condition.

\section{Conclusion}

The aerobic composting duration was considerably shortened to 9 days from the traditional composting period of 45 days, using a novel pre-cultured seed inoculum enzyme obtained from Jaggery and curd. The natural debasement of VMCW was $42 \%(82 \pm 2.83 \%$ to $40.82 \pm 0.61 \%)$, with a volume decrease from $0.012 \mathrm{~m} 3$ to 0.003 $\mathrm{m} 3$ inside 9 days. An improved supplements NPK level of manure bio-compost was recorded as $0.91 \% \mathrm{w} / \mathrm{w}, 0.5 \%$ $\mathrm{w} / \mathrm{w}$ and $1.029 \% \mathrm{w} / \mathrm{w}$ separately. This was evident with an increased microbial population by the plate count confirmed with a lag phase of microbial growth on 2 nd day with an acidic $\mathrm{pH}$, lower growth $(\mathrm{CFU} / \mathrm{mL})$. The shortened $\log$ phase on 5 th day was attributed to an optimum temperature, $\mathrm{C} / \mathrm{N}, \mathrm{pH}$ coincided with high VS and 
volume reduction. The observed bio-kinetic constants based on the microbial count, substrate concentration was recorded as $\mathrm{Km}$ of 81.06 , and $\mathrm{K} 3$ of 0.15 coincided with size and volume reduction. The enriched nutrients confirmed the reduced composting period, and this was further confirmed by the XRD analysis. Fertilizer development seen through the X-beam diffraction (XRD) examination of the excrement affirmed the transformation of the precious stone structure of the manure molecule to indistinct structure and the mineralization of natural issue during the treating of the soil. The lower $\mathrm{K} 3$ and improved microbial composition depicted an enhanced composting process in aid of pre-cultured bacteria/enzymes becoming a better alternative for VMCW degradation that can reduce the land requirement. In this way, the aged pre-refined seed inoculums supported an improved supplements level with abbreviated fertilizing soil time.

Received: 3 March 2020; Accepted: 25 September 2020

Published online: 13 November 2020

\section{References}

1. Kumar, S. et al. Challenges and opportunities associated with waste management in India. R. Soc. Open Sci. 4, 160-164. https:// doi.org/10.1098/rsos.160764 (2017).

2. Mageswari, S. et al. Contamination of groundwater quality due to municipal solid waste disposal-a GIS-based study in Perungudi Dump Yard. Int. J. Eng. Technol. 4, 952-964 (2017).

3. Alexander, R. Compost markets grow with environmental applications. Biocycle 40, 4 (1999).

4. Gautam, S. P., Bundela, P. S., Pandey, A. K. \& Sarsaiya, S. Composting of municipal solid waste of Jabalpur City Central Pollution Control Board, New Delhi, India. Glob. J. Environ. Res. 4, 43-46 (2010).

5. Guo, R. et al. Effect of aeration rate, $\mathrm{C} / \mathrm{N}$ ratio and moisture content on the stability and maturity of compost. Bioresour. Technol. 112, 171-178. https://doi.org/10.1016/j.biortech.2012.02.099 (2012).

6. Pan, I., Dam, B. \& Sen, S. K. Composting of common organic wastes using microbial inoculants. 3 Biotech 2, 127-134. https://doi. org/10.1007/s13205-011-0033-5 (2012).

7. Pichler, M., Knicker, H. \& Kogel-Knabner, I. Changes in the chemical structure of municipal solid waste during composting as studied by solid-state dipolar dephasing and PSRE 13C NMR and solid-state 15N NMR spectroscopy. Environ. Sci. Technol. 34, 4034-4038 (2000).

8. Steger, K., Sjögren, A. M., Jarvis, A., Jansson, J. K. \& Sundh, I. Development of compost maturity and Actinobacteria populations during full-scale composting of organic household waste. J. Appl. Microbiol. 103, 487-498. https://doi.org/10.111 $1 / j .1365-2672.2006 .03271 . x(2007)$.

9. Tiquia, S. M. \& Tam, N. F. Y. Co-composting of spent pig litter and sludge with forced-aeration. Bioresour. Technol. 72, 1-7. https ://doi.org/10.1016/S0960-8524(99)90092-5(2000).

10. Zhu, N. Composting of high moisture content swine manure with corncob in a pilot-scale aerated static bin system. Bioresour. Technol. 97, 1870-1875. https://doi.org/10.1016/j.biortech.2005.08.011 (2006).

11. Finstein, M. S., Miller, F. C. \& Psarianos, K. M. Composting Ecosystem Management for Waste Treatment. Nat. Biotechnol. 1, 347-353 (1983).

12. Kayhanian, M. \& Tchobanoglous, G. Computations of $\mathrm{C} / \mathrm{N}$ ratio for various organic fractions. Biocycle 33, 58-60 (1992).

13 Elving, J., Ottoson, J. R., Vinneras, B. \& Albihn, A. Growth potential of feacal bacteria in simulated psychrophilic/ mesophilic zones during composting of organic waste. J. Appl. Microbiol. 108(6), 1974-1981 (2010).

14 Erickson, M. C., Liao, J., Ma, L., Jiang, X. \& Doyle, M. P. Inactivation of Salmonella spp. in cow manure composts formulated to different initial C:N ratios. Bioresour. Technol. 100, 5898-5903. https://doi.org/10.1016/j.biortech.2009.06.083 (2009).

15. Fourti, O., Jedidi, N. \& Hassen, A. Comparison of methods for evaluating stability and maturity of co-composting of municipal solid wastes and sewage sludge in semi-arid pedo-climatic condition. Nat. Sci. 03, 124-135. https://doi.org/10.4236/ns.2011.32018 (2011).

16. Sanmanee, N., Panishkan, K., Obsuwan, K. \& Dharmvanij, S. Study of compost maturity during humification process using UVspectroscopy. World Acad. Sci. Eng. Technol. 80, 403-405 (2011).

17. Wu, L. \& Ma, L. Q. Relationship between compost stability and extractable organic carbon. J. Environ. Qual. 31, 1323-1328. https ://doi.org/10.2134/jeq2002.1323 (2002).

18. Mukai, S. \& Oyanagi, W. Decomposition characteristics of indigenous organic fertilizers and introduced quick compost and their short-term nitrogen availability in the semi-arid ethiopian rift valley. Sci. Rep. 1, 1-11 (2019).

19. Ryckeboer, J., Mergaert, J., Coosemans, K. \& Deprins, J. Swings, Microbiological aspects of biowaste during composting in a monitored compost bin. J. Appl. Microbiol. 94, 1 (2002).

20. Finstein, M. S., Miller, F. C. \& Strom, P. F. Waste treatment composting as a controlled system. Biotechnology 8, 363-398 (1986).

21 Kumar, S., Sakhale, A. \& Mukherjee, S. Simplified Kinetic Analysis for Composting of Municipal Solid Waste. Pract. Period. Hazardous Toxic. Radioact. Waste Manag. 13, 179-186. https://doi.org/10.1061/(ASCE)1090-025X(2009)13:3(179) (2009).

22. Diaz, M. J., Madejon, E., Lopez, F., Lopez, R. \& Cabrera, F. Optimization of the rate vinasse/grape marc for co-composting process. ProcessBiochem. 37, 1143-1150 (2002)

23. Rynk, R. (ed.) On-farm composting handbook (Northeast Regional Agricultural Engineering Service, Ithaca, NY, 1992).

24. Brodie, H. L., Carr, L. E. \& Condon, P. A comparison of static pile and turned windrow methods for poultry litter compost production. Compost Sci. Util. 8, 178-189. https://doi.org/10.1080/1065657X.2000.10701990 (2000).

25. Antunes, L. P., Martins, L. F. \& Setubal, J. C. Microbial community structure and dynamics in thermophilic composting viewed through metagenomics and metatranscriptomics. Sci. Rep. 6, 1-13 (2016).

26. Himanen, M. \& Hänninen, K. Composting of bio-waste, aerobic and anaerobic sludges - Effect of feedstock on the process and quality of compost. Bioresour. Technol. 102, 2842-2852. https://doi.org/10.1016/j.biortech.2010.10.059 (2011).

27. Jokela, J. et al. Aerobic composting and anaerobic digestion of pulp and paper mill sludges. Water Sci. Technol. 36, 181-188. https ://doi.org/10.1016/S0273-1223(97)00680-X (1997).

28. Kalemelawa, F. et al. An evaluation of aerobic and anaerobic composting of banana peels treated with different inoculums for soil nutrient replenishment. Bioresour. Technol. 126, 375-382. https://doi.org/10.1016/j.biortech.2012.04.030 (2012).

29. Rihani, M. et al. In-vessel treatment of urban primary sludge by aerobic composting. Bioresour. Technol. 101, 5988-5995. https:// doi.org/10.1016/j.biortech.2010.03.007 (2010).

30. Zhu, N. Effect of low initial C/N ratio on aerobic composting of swine manure with rice straw. Bioresour. Technol. 98, 9-13 (2007).

31. He, Y. et al. Evolution of microbial community diversity and enzymatic activity during composting. Res. Microbiol. 164, 189-198. https://doi.org/10.1016/j.resmic.2012.11.001 (2013).

32. Ohtaki, A. N., Sato, N. \& Nakasaki, K. Biodegradation of poly- $\varepsilon$-caprolactone under controlled composting conditions. Polym. Degrad. Stab. 61, 499-505 (1998). 
33. Sobrate, N., Mohee, M.F., Driver, A., Mudhoo, Survival kinetics of faecal bacterial indicators in spent broiler litter composting, J. Appl. Microbiol. 104, (2007)

34. Gabhane, J. et al. Additives aided composting of green waste: effects on organic matter degradation, compost maturity, and quality of the finished compost. Bioresour. Technol. 114, 382-388. https://doi.org/10.1016/j.biortech.2012.02.040 (2012).

35. Partanen, P., Hultman, J., Paulin, L., Auvinen, P. \& Romantschuk, M. Bacterial diversity at different stages of the composting process. BMC Microbiol. 10, 94. https://doi.org/10.1186/1471-2180-10-94 (2010).

36. Iqbal, M. K., Shafiq, T. \& Ahmed, K. Characterization of bulking agents and its effects on physical properties of compost. Bioresour. Technol. 101, 1913-1919. https://doi.org/10.1016/j.biortech.2009.10.030 (2010).

37. APHA, Standard Methods for the Examination of Water and Waste Water; 20 th Ed. American Public Health association; American Water Works Association Water Pollution Control Federation. Washington. DC, USA. 126-130 (1998).

38. Lawal-Akinlami, H. A. \& Shanmugam, P. Comparison of biochemical methane potential and methanogen morphology of different organic solid wastes co-digested anaerobically with treatment plant sludge. Process Saf. Environ. Prot. 107, 216-226. https://doi. org/10.1016/j.psep.2017.02.001 (2017).

39. Razmjoo, P., Pourzamani, H., Teiri, H. \& Hajizadeh, Y. Determination of an empirical formula for organic composition of mature compost produced in Isfahan-Iran composting plant in 2013. Int. J. Environ. Health Eng. 4, 1-6. https://doi.org/10.4103/22779183.153988 (2015).

40. Channiwala, S. A. \& Parikh, P. P. A unified correlation forestimating HHV of solid, liquid and gaseous fuels. Fuel 81, 1051-1063 (2002).

41. Pellera, F. M., Pasparakis, E. \& Gidarakos, E. Consecutive anaerobic-aerobic treatment of the organic fraction of municipal solid waste and lignocellulosic materials in laboratory-scale landfill-bioreactors. Waste Manag. (Oxford) 56, 181-189 (2016).

42. Rittmann, B.E., McCarty, P.L., Environmental biotechnology:principles and applications. In: Stoichiometry and Bacterial Energetic. McGraw Hill Education Inc., New Delhi, India, 2, 126-130, (2012).

43. Kalamdhad, A. S. \& Kazmi, A. A. Rotary drum composting of different organic waste mixtures. Waste Manag. Res. 27, 129-137. https://doi.org/10.1177/0734242X08091865 (2009).

44. Kong, Z. et al. Evolution of various fractions during the windrow composting of chicken manure with rice chaff. J. Environ. Manag. 207, 366-377. https://doi.org/10.1016/j.jenvman.2017.11.023 (2018).

45. Beffa, T. et al. Isolation of Thermus Strains from Hot Composts $\left(60\right.$ to $\left.80^{\circ} \mathrm{C}\right)$. Appl. Environ. Microbiol. 62, 1723-1727 (1996).

46. Chang, Y. The fungi of wheat straw compost. Trans. Br. Mycol. Soc. 50, 667-677. https://doi.org/10.1016/S0007-1536(67)80098-6 (1967).

47. Gray, K. R., Sherman, K. \& Diddlestone, A. J. A review of composting: Part 1. Process Biochem. 31, 32-36 (1971).

48. Strom, P. F. Identification of thermophilic bacteria in solid waste composting. Appl. Environ. Microbiol. 50, 906-913 (1985).

49. Khan, H. Z., Malik, M. A. \& Saleem, M. F. Effect of rate and source of organic material on the production potential of spring maize (Zea mays L). Pak. J. Agric. Sci. 45, 40-43 (2008).

50. Zorpas, A. A. et al. Compost produced from organic fraction of municipal solid waste, primary stabilized sewage sludge and natural zeolite. J. Hazard. Mater. 77, 149-159. https://doi.org/10.1016/S0304-3894(00)00233-8 (2000).

51. Chai, E. W. et al. Compost feedstock characteristics and ratio modelling for organic waste materials co-composting in Malaysia. Environ. Technol. 20, 2859-2866. https://doi.org/10.1080/09593330.2013.795988 (2013).

52. Awasthi, M. K., Pandey, A. K., Bundela, P. S. \& Khan, J. Co-composting of organic fraction of municipal solid waste mixed with different bulking waste: Characterization of physicochemical parameters and microbial enzymatic dynamic. Bioresour. Technol. 182, 200-207. https://doi.org/10.1016/j.biortech.2015.01.104 (2015).

53. Karak, T., Bhagat, R. M. \& Bhattacharyya, P. Municipal solid waste generation, composition, and management: the world scenario. Crit. Rev. Environ. Sci. Technol. 42, 1509-1630. https://doi.org/10.1080/10643389.2011.569871 (2012).

54. Makan, A. \& Mountadar, M. Effect of $\mathrm{C} / \mathrm{N}$ ratio on the in-vessel composting under air pressure of organic fraction of municipal solid waste in Morocco. J. Mater. Cycles Waste Manag. 14, 241-249. https://doi.org/10.1007/s10163-012-0062-0 (2012).

55. Makan, A., Assobhei, O. \& Mountadar, M. Effect of initial moisture content on the in-vessel composting under air pressure of organic fraction of municipal solid waste in Morocco. Iran. J. Environ. Health Sci. Eng. 10, 1-9. https://doi.org/10.1186/1735-274610-3 (2013).

56. Fialho, L. L., da Silva, W. T. L., Milori, D., Simoes, M. L. \& Martin-Neto, L. Characterization of organic matter from composting of different residues by physicochemical and spectroscopic methods. Bioresour. Technol. 101, 1927-1934 (2010).

57. Clesceri, N. L. Special issue: monitoring and characterization techniques for contaminants in the subsurface. J. Environ. Eng. ASCE. 124, 489 (1998).

58. Stainforth, A. R. Cereal Straw (Clarendon Press, Oxford, 1979).

59. Raclavska, H., Juchelkova, D., Skrobankova, H., Wiltowski, T. \& Campen, A. Conditions for energy generation as an alternative approach to compost utilization. Environ. Technol. 32(4), 407-417. https://doi.org/10.1080/09593330.2010.501089 (2011).

60. Ekinci, K., Keener, H. M. \& Akbolat, D. Effects of feedstock, airflow rate, and recirculation ratio on performance of composting systems with air recirculation. Biores. Technol. 97, 922-932 (2006).

61. Steppa, M. Two options for energy recovery from waste biomass. MaszynyiCiagnikiRolnicze. 3, 85-89 (1988).

62. Sobel, T. \& Muck, R. E. Energy in animal manures. Energy Agric. 2, 161-176 (1983).

63. Harper, E., Miller, F. C. \& Macauley, B. J. Physical management and interpretation of an environmentally controlled composting ecosystem. Aust. J. Exp. Agric. 32, 657-667 (1992).

64. Hu, Z. et al. Characterization of organic matter degradation during composting of manure-straw mixtures spiked with tetracyclines. Bioresour. Technol. 102, 7329-7334. https://doi.org/10.1016/j.biortech.2011.05.003 (2011).

65. Saha, J. K., Panwar, N. \& Singh, M. V. An assessment of municipal solid waste compost quality produced in different cities of India in the perspective of developing quality control indices. Waste Manag. 30, 192-201. https://doi.org/10.1016/j.wasman.2009.09.041 (2010).

66. Xi, B., Zhang, G. \& Liu, H. Process kinetics of inoculation composting of municipal solid waste. J. Hazard. Mater. 124, 165-172. https://doi.org/10.1016/j.jhazmat.2005.04.026 (2005).

\section{Author contributions}

Mr. Murugesan designed the Aerobic composting reactor and analyzed the composting strategy of municipal solid waste. Both chemical and analytical characterization of waste has been analysed. Dr. Joshua Amarnath.

\section{Competing interests}

The authors declare no competing interests.

\section{Additional information}

Supplementary information is available for this paper at https://doi.org/10.1038/s41598-020-75766-3.

Correspondence and requests for materials should be addressed to D.J.A. 
Reprints and permissions information is available at www.nature.com/reprints.

Publisher's note Springer Nature remains neutral with regard to jurisdictional claims in published maps and institutional affiliations.

(c) (i) Open Access This article is licensed under a Creative Commons Attribution 4.0 International License, which permits use, sharing, adaptation, distribution and reproduction in any medium or format, as long as you give appropriate credit to the original author(s) and the source, provide a link to the Creative Commons licence, and indicate if changes were made. The images or other third party material in this article are included in the article's Creative Commons licence, unless indicated otherwise in a credit line to the material. If material is not included in the article's Creative Commons licence and your intended use is not permitted by statutory regulation or exceeds the permitted use, you will need to obtain permission directly from the copyright holder. To view a copy of this licence, visit http://creativecommons.org/licenses/by/4.0/.

(C) The Author(s) 2020 